\title{
Cinética do crescimento de Borrelia burgdorferi (Spirochaetaceae) em diferentes meios de cultivo ${ }^{1}$
}

\author{
Angela de Oliveira², Adivaldo H. Fonseca ${ }^{3}$, Márcia M. Ishikawa² e Natalino H. \\ Yoshinari ${ }^{4}$
}

\begin{abstract}
Oliveira A., Fonseca A.H., Ishikawa M.M. \& Yoshinari N.H. 2004. [Cinetic growth of Borrelia burgdorferi (Spirochaetaceae) in different culture media.] Cinética do crescimento de Borrelia burgdorferi em diferentes meios de cultivo. Pesquisa Veterinária Brasileira 24(2):61-64. Depto Epidemiologia e Saúde Pública, Instituto de Veterinária, Universidade Federal Rural do Rio de Janeiro, Seropédica, RJ 23890-000, Brazil. E-mail: adivaldo@ ufrri.br

The cinetic of growth of Borrelia burgdorferi was studied during a 3-month period, using the following 8 culture media: (1) rabbit serum BSK, (2) swine serum BSK, (3) swine serum BSK + 5 fluorouracil, (4) PMR, (5) CTB, (6) Dubos, (7) Brucella broth and (8) BHI. All media were prepared aseptically and were maintained in culture tubes of $10 \mathrm{ml}$ capacity. For each medium, the inoculum was standardized to contain initially $10^{2}$ spirochetes for each $0.1 \mathrm{ml}$ of culture. The growth was monitorized by counting the total number of spirochetes in $0.1 \mathrm{ml}$ of medium in a dark field microscope, using a $10 \times 30 \mathrm{~mm}$ cover slip. For the first 12 days, counting was done each 24 hours, and afterwards once a week during 14 weeks. There occurred growth of $B$. burgdorferi in all tested media, with the best performance of three of them: BSK with rabbit serum, BSK swine serum + 5 fluorouracil, and CTB medium. Growth of B. burgdorferi was seen from the 4th week on, reaching its maximum within 8-12 weeks, depleting the culture medium after this time. Cystic forms of $B$. burgdorferi were observed with all tested media.
\end{abstract}

INDEX TERMS: Culture medium, Borrelia burgdorferi, borreliosis, Spirochaetaceae, bacteria cultivation, cinetic growth, cystic forms.

RESUMO.- Estudou-se a cinética de crescimento de Borrelia burgdorferi, por um período de 3 meses, utilizando os seguintes oito meios de cultivo: (1) BSK adicionado de soro de coelho, (2) BSK adicionado de soro de suíno, (3) BSK adicionado de soro de suíno + 5 fluorouracil, (4) PMR, (5) CTB, (6) Dubos, (7) Caldo Brucella e (8) BHI. Todos os meiosforam preparados assepticamente e mantidos em tubos de ensaio com capacidade para $10 \mathrm{ml}$. Para cada meio, o inoculo foi padronizado para conter no início $10^{2}$ espiroquetas para cada $0,1 \mathrm{ml}$ de cultivo. 0 monitoramento do crescimento foi feito contando-se o total de espiroquetas em 0,1 $\mathrm{ml}$ do meio entre lâmina de microscopia e lamínula com dimen-

\footnotetext{
${ }^{1}$ Recebido em 17 de janeiro de 2001.

Aceito para publicação em 18 de setembro de 2003.

Parte da Tese de Doutorado da autora junto ao Curso de Pós-Graduação em Sanidade Animal, Universidade Federal Rural do Rio de Janeiro (UFRRJ). Trabalho realizado com suporte financeiro do CNPq.

2 Doutoranda Sanidade Animal e CPGMV-PV, UFRRJ, Seropédica, RJ 23890000 .

${ }^{3}$ Depto Epidemiologia e Saúde Pública, UFRRJ. E-mail: adivaldo@ ufrrj.br

${ }^{4}$ Depto Reumatologia, Faculdade de Medicina, Universidade de São Paulo.
}

sões de 10x30mm, tendo sido utilizado microscópio de campo escuro. A contagem foi realizada durante 14 semanas, tendo sido diária nos primeiros 12 dias esemanal a partir desta data. Houve crescimento de B. burgdorferi em todos meios testados, com meIhor performance para três deles: BSK adicionado de soro de coeIho, BSK adicionado de soro de suíno + 5 fluorouracil e meio CTB. Observou-se crescimento de B. burgdorferi a partir da 4a semana, atingindo o platô de crescimento entre a $8^{\mathrm{a}}$ e $12^{\mathrm{a}}$ semanas, quando começou a exaustão do meio de cultivo. Formas císticas de B. burgdorferi foram observadas em todos os meios testados.

TERMOS DE INDEXAÇÃO: Meios de cultivo, Borrelia burgdorferi, borreliose, Spirochaetaceae, cultivo de bactérias, cinética de crescimento, formas císticas.

\section{INTRODUÇÃO}

A espécie Borrelia burgdorferi Johnson, Schmid, Hyde, Steigerwalt, Brenner 1984, é cosmopolita, acomete animais silvestres, domésticose seres humanos, sendo transmitida por carrapatos. Animais sofrem doença benigna e desempenham papel de sentinela para o monitoramento da dispersão do agente em novas áreas geográficas (Lissman et al. 1984, Parker \& White 1992). B. burgdorferi cres- 
ce à temperatura de 330 $\mathrm{C}$ e pode ser visualizada através de microscopia de campo escuro, de contraste de fase ou ainda em cortes histológicos, quando impregnados por corantes à base de prata (Barbour \& Hayes 1986, Quinn et al. 1994).

Os meios utilizados para cultivo são altamente enriquecidos, de custo elevado e como o período de incubação é longo, tornase fácil o crescimento de microrganismos contaminantes, impedindo o seu desenvolvimento. Preac-Mursic et al. (1991) cultivaram B. burgdorferi em seis meios sólidos utilizando soro de coeIho e albumina sérica bovina. Para tornar esses meios seletivos os autores adicionaram co-trimoxazole, amicacina, fosfomicina e outros antibióticos. Após a incubação em jarras, com vela e na de Gaspak, por um período de 2 a 4 semanas, as colônias de Borrelia sp foram contadas e sua morfologia caracterizada.

Os objetivos deste trabalho foram testar diferentes meios modificados e de baixo custo para cultivo de B. burgdorferi, bem como estudar a cinética do crescimento em meios selecionados.

\section{MATERIAL E MÉTODOS}

A amostra padrão de Borrelia burgdorferi (Cepa G39/40) foi proveniente do Laboratório de Doença de Lyme da Faculdade de Medicina da Universidade de São Paulo. Esta amostra foi conservada em tubos "nunc" contendo meio BSK com $80 \%$ de glicerol estéril, em botijão de nitrogênio líquido.

Os seguintes meios de cultura foram utilizados para crescimento das espiroquetas: BSK-coelho, BSK-suíno, BSK-suíno + 5-fluorouracil, PMR, CTB, Dubos, Caldo Brucella e BHI. Todos os meios foram adicionados 0,3\%de agar-agar e $6 \%$ de soro de suíno. Em cada tubo com $3 \mathrm{ml}$ de meio foram inoculados $10 \mathrm{ml}$ das culturas de B. burgdorferi. Todos os tubos foram incubados a $34^{\circ} \mathrm{C}$. Todos os meios foram preparados assepticamente e mantidos em tubos de ensaio com capacidade para $10 \mathrm{ml}$. Para cada meio de cultivo o inoculo foi padronizado de modo a conter, no início, $10^{2}$ espiroquetas para cada $0,1 \mathrm{ml}$ de cultivo.

Para contagem das espiroquetas, $10 \mathrm{ml}$ da cultura homogeneizada, foi colocada sobre lâmina de microscopia com dimensões de $26 \times 76 \mathrm{~mm}$ e coberta com lamínula de $30 \times 10 \mathrm{~mm}$. A contagem das espiroquetas foi feita com aumento de $250 x$ ou superior, pela microscopia de campo escuro ou contraste de fase. Esta contagem foi feita diariamente, até o 12 dia; a partir desta data a contagem foi realizada 2 vezes por semana, até a 14 a semana. Quando o número de espiroquetas aumentou, inviabilizando a contagem, tornou-se necessário promover diluições seriadas, em salina, para as concentrações $1 / 10 ; 1 / 100$ ou 1/1000.

\section{RESULTADOS E DISCUSSÃO}

Todos os meios utilizados foram eficientes como substrato para crescimento de Borrelia. burgdorferi (Fig. 1 e 2). Foram observadas pequenas oscilações nos números de células nos primeiros 12 dias, cuja contagem permaneceu entre 20 e 140 unidades por 0,1 ml de meio (Fig. 1). A partir da segunda semana, foi observado discreto crescimento em todos os meios, com o platô de crescimento entre a $8^{a}$ e $13^{\text {a }}$ semanas, a partir de quando houve significativo decréscimo na contagem (Fig. 2). Os meiosà base de BSK, propiciaram melhores condições para crescimento, tendo atingido o número de $1,2 \times 10^{3}$ células na $12^{a}$ semana. Após 100 dias, as espiroquetas apresentavam-se finas, sem espiral e em número reduzido.
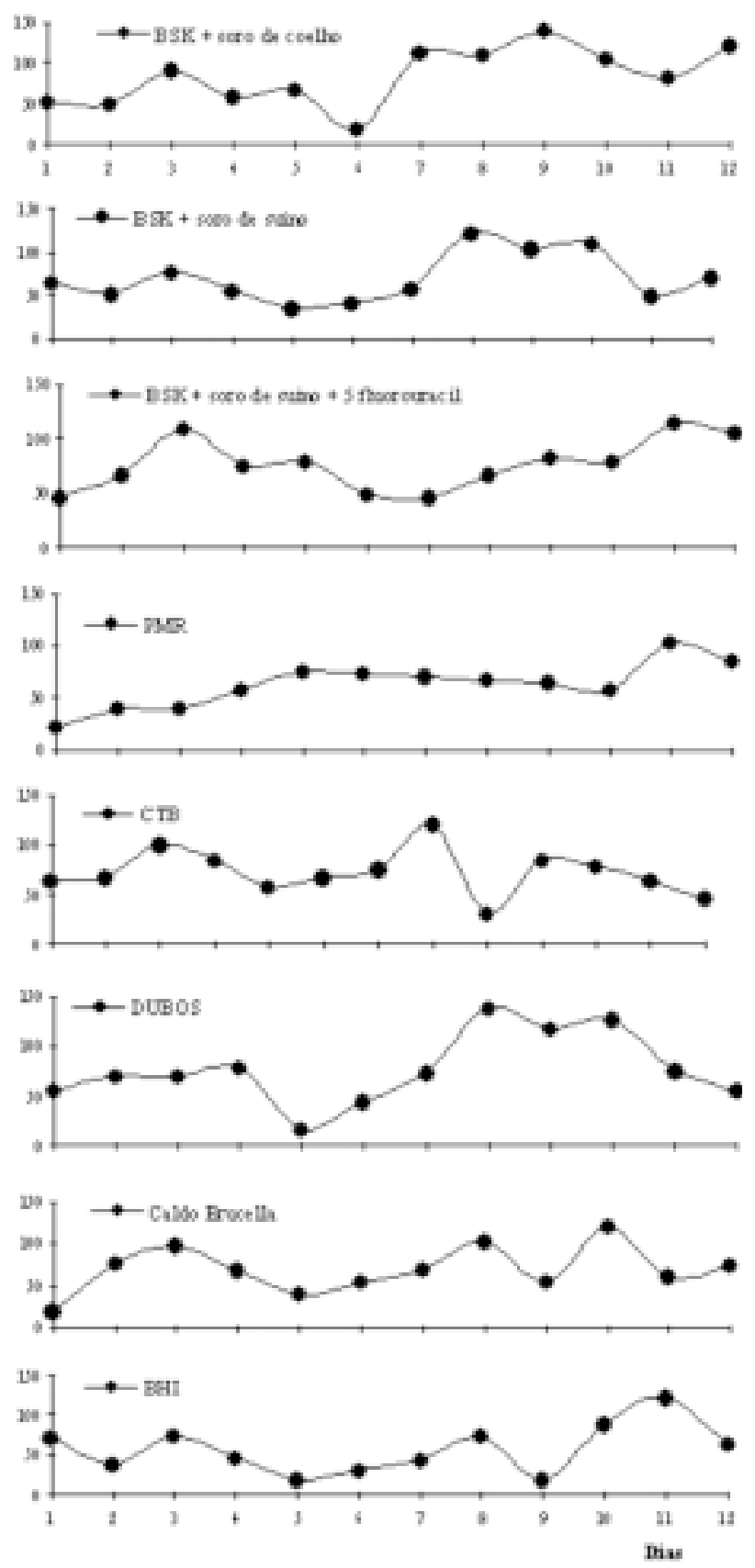

Fig. 1. Cinética de crescimento em dias de Borrelia burgdorferi nos meios BSK-coelho, BSK-suíno, BSK-suíno + 5-fluorouracil, PMR, CTB, Dubos, Caldo Brucella e BHI.

Bahrmand et al. (1996) descreveram um meio sólido para o crescimento de B. microti e B. persica, e demonstraram a redução do tempo de cultivo para 72 horas, o que permitiu um diagnóstico mais rápido. Estes autores obtiveram uma curva de crescimento para as duas amostras trabalhadas. Heroldova et al. (1998) estudaram o tempo de geração de B. burgdorferi em diversas temperaturas, e observaram que na variação de temperatura entre $25^{\circ} \mathrm{C}$ a $27^{\circ} \mathrm{C}$ o tempo de geração foi de 8:26 e 12:36 horas. 


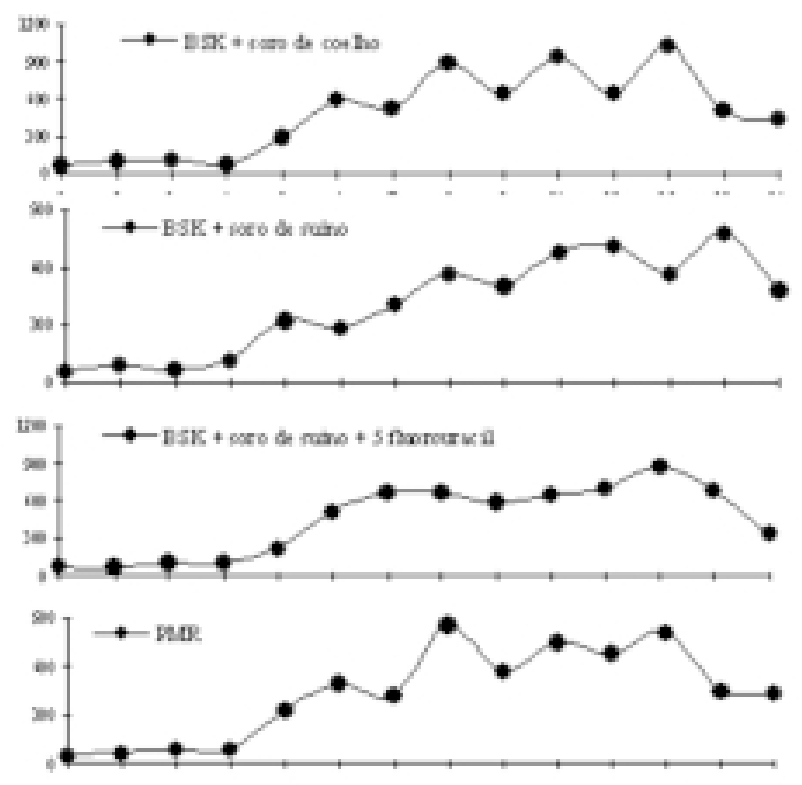

componentes proteináceos, tais como a al bumina sérica bovina, a origem e qualidade do soro como fatores críticos que afetam a dinâmica do crescimento das espiroquetas. Segundo Barbour (1986) e Wittenbrink et al. (1996), a albumina sozinha ou em combinação com soro de coelho fornece os ácidos graxos de cadeia longa que são incorporados dentro dos lipídeos da célula. 0 efeito do piruvato de sódio sobre o crescimento de Borrelia spp in vitro, estimula a glicólise quando presente em concentrações baixas. Callister et al. (1990), demonstraram que a fração V da albumina sérica bovina, usada no meio de BSK pode afetar a recuperação de borrelias.

Trabalho de Wittenbrink et al. (1996), indicou que em mais de 50 amostras de B. burgdorferi o crescimento foi bastante rápido com a adição de até 2,5\%de albumina sérica bovina. Em todas as amostras testadas, segundo os autores, a morfologia celular e a motilidade foram preservadas. 0 efeito do piruvato de sódio sobre o crescimento de Borrelia in vitro, estimula a glicólise quando presente em concentração baixa. Segundo Barbour (1986), B. burgdorferi é mais móvel em suspensões, a qual é acentuada quando se adiciona glicose ao meio de cultura.

Formas císticas de B. burgdorferi foram observadas com mai-
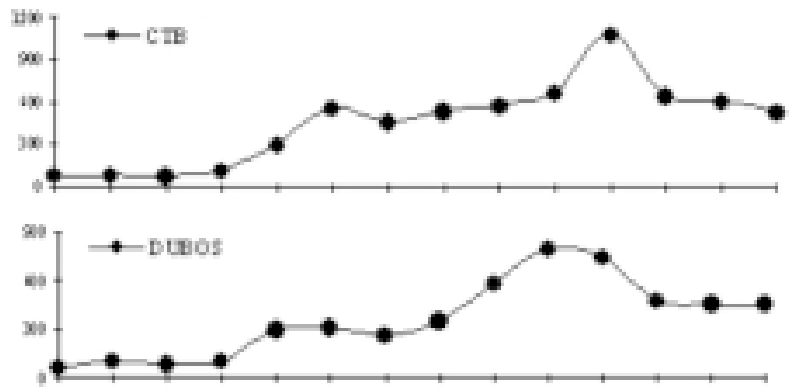
or freqüência nos meios de cultivo desfavoráveis, mas ocorreu também em meios favoráveis como no BSK. Segundo Brorson \& Brorson (1997), condições desfavoráveis, representadas pela presença de antibióticos, estimulam a presença de formas císticas, e que este estado de baixa atividade é importante para sua sobrevivência em ambiente negativo. A eficácia do antibiótico requer um metabolismo ativo da bactéria, sendo provável que a forma cística de B. burgdorferi constitua uma forma resistente ao tratamento com antibiótico. Este fenômeno, segundo Brorson \& Brorson (1997), pode explicar as razões da borreliose de Lyme ser de difícil tratamento em al guns pacientes e que as membranas que circundam as formas encistadas as proteja contra estresse externo. No presente trabalho, foi observado reversão de formas espiraladas em formas císticas e vice-versa. Brorson \& Brorson (1997) observaram a reversão para forma espiralada quando os cistos foram colocados no mesmo meio de cultura adicionado de soro, no qual elas se apresentavam móveis e espiraladas. É provável que fenômeno semelhante ocorra in vivo, em condições não favoráveis para estes microrganismos, eque estas observações podem auxiliar o diagnóstico e tratamento de infecções causadas em humanos e em animais.

Fig. 2. Cinética de crescimento em semanas, de Borrelia burgdorferi nos meios BSK-coelho, BSK-suíno, BSK-suíno + 5-fluo rouracil, PMR, CTB, Dubos, Caldo Brucella e BHI.

Dodge (1973) isolou B. recurrentis utilizando vários meios enriquecidos e referiu-se ao grau elevado de exigência da espécie, quanto ao conteúdo dos meios. Na avaliação dos meios utilizados concluiu que todos eles foram capazes de suportar o crescimento ativo do microrganismo testado, e que nenhum crescimento ocorreu quando a albumina era retirada do meio. No presente trabalho foi observado crescimento de B. burgdorferi nos mesmos meios relacionados por Dodge (1973), e até mesmo nos meios com ausência da al bumina.

Pollack et al. (1993) comentaram sobre a importância dos

\section{REFERÊNCIAS}

Bahrmand A.R., Nekoui H. \& Ardekani A.M. 1996. Nuevo medio sólido para el crecimiento de B. persica y B. microti. Rev. Cubana Med. Trop. 48 (1):40-44.

Barbour A.G. \& Hayes S.F. 1986. Biology of Borrelia species. Microbiol. Rev. 50(4):381-400.

Brorson O. \& Brorson S.H. 1997. Transformation of cystic forms of B. burgdorferi to normal, mobile Spirochetes. Infection 25 (4):240 -246.

Callister S.M., Case K.L., Agger, W.A., Schell R.F., Johnson S.M. \& Ellingson J.L.E. 1990. Effects of bovine serum albumin on the ability of BarbourStoenner-Kelly Medium to detect Borrelia burgdorferi. J. Clin. Microbiol. 28(2):363-365.

Dodge R.W. 1973. Culture of ethiopian of Borrelia recurrentis. Appl. Microbiol. 25(6):935-939. 
Heroldova M., Nemec M. \& Hubalek Z. 1998. Growth parameters of Borrelia burgdorferi sensu stricto at various temperatures. Zbl. Bakt. 288(4):451455.

Lissman B.A., Bosler, E.M., Camay, H., Ormiston, B.G. \& Benach J.L. 1984. Spirochetes associated arthritis (Lyme disease) in a dog. J. Am. Vet. Med. Assoc. 185 (2):219-220.

Pollack R.J., Telford S.R., Spielman A. 1993. Standartization of medium for culturing Lyme diseases spirochetes. J. Clin. Microbiol. 3:12511255.
Parker J.L. \& White K.W. 1992. Lyme borreliosis in cattle and horses: a review of the literature. Cornell Vet. 82:253-274.

Preac-Mursic V., Wilske B. \& Reinhardt S. 1991. Culture of Borrelia burgdorferi on six solid media. Europ. J. Clin. Microbiol. Infect. Dis. 10(12):10761079.

Quinn P.J., Carter M.E., Markey, B.K. \& Carter G.R. 1994. Clinical Veterinary Microbiology. 1st ed,. Wolfe Publishing, London, p.292-303.

Wittenbrink M.M., Reuter C., Manz M.L. \& Krauss H. 1996. Primary culture of B. burgdorferi from Ixodes ricinus ticks. Zbl. Bakt. 285(1):20-28. 